\title{
Upaya Peningkatan Kemampuan Pemecahan Masalah dan Hasil Belajar Peserta Didik melalui Penerapan Metode Cooperative Problem Solving
}

\author{
Viona Junita Sari, Connie, Eko Swistoro \\ Program Studi Pendidikan Fisika Jurusan Pendidikan MIPA \\ Universitas Bengkulu \\ Email : vionaraher@gmail.com
}

\begin{abstract}
ABSTRAK
Penelitian ini bertujuan untuk mendeskripsikan peningkatan aktivitas belajar, kemampuan pemecahan masalah, dan hasil belajar pengetahuan peserta didik. Subjek dalam penelitian ini adalah seluruh siswa kelas X IPA 2 SMAN 10 Kota Bengkulu yang berjumlah 33 Orang. Hasil penelitian ini menunjukan bahwa rata-rata aktivitas belajar peserta didik pada siklus I adalah sebesar 26,5 dalam kategori cukup, siklus II sebesar 30,5 dalam kategori baik, dan siklus III sebesar 34,5 dalam kategori baik. Kemampuan pemecahan masalah peserta didik pada siklus I diperoleh sebesar 68,18, siklus II sebesar 76,94 dan siklus III sebesar 87,04. Hasil belajar diperoleh daya serap sebesar $67,12 \%$ dan ketuntasan belajar klasikal sebesar 54,54\%, meningkat pada siklus II yaitu daya serap sebesar 75,15\% dan ketuntasan belajar klasikal sebesar $81,81 \%$, kemudian untuk siklus III, dan meningkat lagi untuk siklus III daya serap sebesar $84,85 \%$ dan ketuntasan belajar sebesar $100 \%$. Berdasarkan hasil penelitian bahwa penerapan metode Cooperative Problem Solving pada konsep usaha dan energi di kelas X IPA 2 dapat meningkatkan aktivitas belajar, kemampuan pemecahan masalah, dan hasil belajar peserta didik.
\end{abstract}

Kata Kunci : Metode Cooperative Problem Solving, aktivitas belajar peserta didik, kemampuan pemecahan masalah peserta didik, hasil belajar peserta didik.

\begin{abstract}
This research aimed to describe the learning activity enhancement, problem solving skills and student learning outcomes. Subject in this research was 33 students of X IPA 2 SMAN 10, Bengkulu City. The result showed that the students learning activity average on cycle I was equal to 26,5 in sufficient category. Cycle II was 30,5 in good category and cycle III was 34,5 in good category. Students problem solving skills on cycle I was obtained 68,18 in , cycle II was 76,94 and cycle III was 87,04. Knowledge learning outcomes on cycle I was obtained the comprehensibility $67,12 \%$ and classical study mastery was $54,54 \%$, increased on cycle II with the comprehensibility was $75,15 \%$ and classical study mastery was $81,81 \%$, then increased more on cycle III, the comprehensibility was $84,84 \%$ and classical study mastery was $100 \%$. Based on the research can be concluded that the application of cooperative problem solving method on effort and energy concepts in X IPA 2 can improve the learning activity, problem solving skills and student learning outcome.
\end{abstract}

Keyword: Cooperative Problem Solving Method, learning activity enhancement, problem solving skills student learning outcomes.

\section{PENDAHULUAN}

Fisika adalah mata pelajaran yang lahir dari ilmu pengetahuan alam yang mempelajari tentang fenomena-fenomena yang sering kita alami di kehidupan sehari-hari. Dalam pembelajaran fisika, bukan hanya membutuhkan pemahaman konsep saja karena fisika merupakan pelajaran yang tidak hanya mengandung teori tetapi fisika juga mengandung rumus-rumus yang juga membutuhkan kemampuan pemecahan masalah.

Fisika mengharuskan peserta didik untuk mengerti dan memahami (to understand) konsep-konsep tersebut bukan hanya sekedar tahu (knowing), dan hafal (memorizing) serta peserta didik diharapkan dapat menghubungkan suatu konsep dengan konsep lain yang saling berkaitan [1]. Oleh karena itu, keberhasilan dan keefektifan dalam pembelajaran fisika dapat 
dilihat dari kemampuan pemecahan masalah dan adanya perubahan-perubahan pada hasil belajar yaitu hasil belajar kognitif, afektif dan psikomotorik pada peserta didik.

Menurut Hoellwarth, dkk (2005), pembelajaran dalam kelas cenderung menekankan pada penguasaan konsep dan mengesampingkan kemampuan pemecahan masalah fisika peserta didik. Peserta didik mengalami kesulitan ketika berhadapan dengan permasalahan yang kompleks. Menurut Redish (2005), peserta didik mampu menyelesaikan pemasalahan kuantitatif sederhana namun kurang memiliki kemampuan untuk menyelesaikan masalah yang lebih kompleks. Padahal, salah satu tujuan pembelajaran fisika menurut Walsh dkk (2007), adalah membentuk manusia yang dapat memecahkan masalah kompeks dengan cara menerapkan pengetahuan dan pemahaman mereka pada situasi sehari-hari [1].

Berdasarkan observasi yang telah dilakukan di kelas X IPA 2 SMAN 10 Kota Bengkulu, pada saat proses pembelajaran berlansung guru cenderung lebih aktif dibanding peserta didik. Pada saat mengajar, guru jarang menggunakan metode pembelajaran yang menuntut peserta didik mencari atau memecahkan sendiri masalah pembelajaran, guru juga masih cenderung menjelaskan konsep dan mengesampingkan kemampuan pemecahan masalah pada peserta didik. Setelah guru menjelaskan materi pelajaran, peserta didik biasanya hanya diberikan contoh-contoh soal yang ada di dalam buku paket. Setelah peserta didik diberi soal oleh guru, hanya sebagian saja peserta didik yang ingin mengerjakan soal di depan kelas itupun jika ditunjuk oleh guru bukan peserta didik sendiri yang mengacungkan tangan. Dilihat dari kebiasaan ini, peserta didik merasa kesulitan memecahkan masalah yang dicontohkan oleh guru, apalagi ketika masalah tersebut diubah menjadi masalah kompleks, peserta didik akan lebih kesulitan bahkan tidak bisa untuk memecahkan masalah tersebut. Hal tersebut terjadi karena kurangnya kerja sama atau komunikasi antar peserta didik serta peserta didik tidak berani menyampaikan pertanyaan-pertanyaan akan suatu materi yang belum dipahami kepada guru maupun sesama peserta didik atau bahkan peserta didik cenderung diam dan tidak memperhatikan pelajaran. Padahal dalam pembelajaran fisika, selain hasil belajar, sangat diperlukan peserta didik yang aktif dan memiliki kemampuan pemecahan masalah yang baik.

Berdasarkan hasil belajar yang diperoleh peserta didik, hanya sekitar 15 orang peserta didik yang mampu mencapai KKM serta rentang nilai yang diperoleh peserta didik dari nilai tertinggi ke nilai terendah sangat jauh berbeda. Untuk itu diperlukan metode pembelajaran yang dapat membuat peserta didik menjadi lebih aktif dan berani serta memiliki sikap kerja sama (sosial) yang baik antar sesama peserta didik agar dapat meningkatkan kemampuan pemecahan masalah dan hasil belajar peserta didik.

Berdasarkan diskusi dengan guru mengenai masalah yang ada di kelas X IPA 2 SMAN 10 Kota Bengkulu dapat di atasi dengan menggunakan metode Cooperative Problem Solving. Karena Cooperative Problem Solving adalah salah satu metode yang menekankan sikap peduli dengan sesama anggota kelompok, dengan kata lain metode ini mengajarkan peserta didik untuk saling bekerja sama dalam memecahkan masalah agar masalah yang dihadapi dapat diselesaikan dengan baik dengan cara saling bertukar pikiran antar anggota kelompok maupun antar kelompok

Metode Cooperative Problem Solving (CPS) adalah salah satu metode yang dapat digunakan oleh guru agar dapat menciptakan pembelajaran yang bersifat student center sesuai dengan kurikulum 2013. Metode CPS dapat diartikan sebagai metode mengajar yang banyak menimbulkan aktivitas belajar karena peserta didik dihadapkan dengan masalah, merumuskan dan menguji kebenaran sampai pada menarik kesimpulan sebagai jawaban dari masalah [2].

Keunggulan Cooperative Problem Solving menurut Heller dan Hollabaugh, yaitu: 1) masalah yang rumit dapat lebih mudah diselesaikan secara berkelompok daripada secara individu; 2) peserta didik memperoleh soal latihan terbimbing dan terampil menggunakan bahasa fisika; 3) saat diskusi satu sama lain, peserta didik harus sepakat dan menyelesaikan 
ulang kesalahpahaman konsep; dan 4) saat brainstorming masalah, peserta didik tidak diintimidasi karena mereka menjawabnya bukan secara individu, tetapi berkelompok [3].

Berdasarkan latar belakang di atas peneliti melakukan penelitian yang berjudul "Upaya Peningkatan Kemampuan Pemecahan Masalah Dan Hasil Belajar Peserta didik Melalui Penerapan Metode Cooperative Problem Solving”. Penelitian ini dilakukan di kelas X IPA 2 SMAN 10 Kota Bengkulu pada konsep usaha dan energi. Adapun rumusan masalah dalam penelitian ini adalah: (1) Bagaimana penerapan metode Cooperative Problem Solving dapat meningkatkan aktivitas belajar peserta didik kelas X IPA 2 SMAN 10 Kota Bengkulu, (2) Apakah penerapan metode Cooperative Problem Solving dapat meningkatkan kemampuan pemecahan masalah peserta didik kelas X IPA 2 SMAN 10 Kota Bengkulu, (3) Apakah penerapan metode Cooperative Problem Solving dapat meningkatkan hasil belajar peserta didik kelas X IPA 2 SMAN 10 Kota Bengkulu.

\section{METODELOGI PENELITIAN}

Penelitian ini merupakan penelitian tindakan kelas yang dilaksanakan sebanyak 3 siklus. Subjek dari penelitian ini adalah kelas X IPA 2 SMAN 10 Kota Bengkulu tahun ajaran 2017/2018, yang berjumlah 33 orang peserta didik, yang terdiri dari 20 orang peserta didik perempuan dan 13 orang peserta didik laki-laki.

Teknik pengumpulan data yang digunakan dalam penelitian ini adalah observasi dan tes akhir siklus. Data yang didapatkan adalah aktivitas siswa dan guru, kemampuan pemecahan masalah, hasil belajar peserta didik pada ranah pengetahuan pada setiap siklus. Aktivitas belajar diamati menggunakan lembar observasi pada setiap siklusnya. Penilaian lembar observasi berpedoman pada kriteria penilaian lembar observasi. Kemampuan pemecahan masalah diajarkan melalui lembar diskusi peserta didik dan untuk melihat kemampuan pemecahan masalah peserta didik, pada akhir siklus diberikan soal tes evaluasi. Tes evaluasi terdiri dari satu soal essay yang mengandung 9 indikator kemampuan pemecahan masalah. Tes hasil belajar pengetahuan pada setiap siklus terdiri atas 2 soal essay.

Instrumen tes pada penelitian ini berupa soal essay. Sebelum instrumen tes digunakan, terlebih dahulu harus uji validitas. Uji validitas digunakan untuk mengetahui kevalidan soal tes yang akan digunakan pada penelitian. Adapun, uji validitas yang digunakan pada penelitian ini adalah uji validitas konten (isi).

Data tes kemampuan pemecahan masalah dianalisis berdasarkan tahap-tahap dalam memecahkan masalah yang dilakukan oleh peserta didik dan ditentukan melalui rubrik penilaian tes.

$$
N A_{i}=\frac{Q_{i} \times 100}{E_{i}}
$$

$$
i=1,2,3,4
$$

Ket :

$1=$ Tahap Memahami Masalah

2 = Tahap Merencanakan Strategi

$3=$ Tahap Menerapkan Strategi

$4 \quad=$ Tahap mengevaluasi Solusi

$\mathrm{Na}_{\mathrm{t}} \quad=$ Nilai siswa untuk setiap tahap

$\mathrm{Q}_{\mathrm{i}} \quad=$ Total skor siswa untuk setiap tahapan

$\mathrm{E} \quad=$ Total skor maksimal untuk setiap tahapan

Kriteria atau kategori kemampuan pemecahan masalah dapat dilihat pada tabel 1:

Tabel 1. Kategori Kemampuan Pemecahan Masalah 


\begin{tabular}{|c|c|}
\hline Nilai & Kategori \\
\hline $0 \leq \mathrm{TKS} \leq 60$ & Rendah \\
\hline $60 \leq \mathrm{TKS} \leq 75$ & Sedang \\
\hline $75 \leq \mathrm{TKS} \leq 100$ & Tinggi \\
\hline
\end{tabular}

1. Nilai Rata-rata

$$
\bar{X}=\frac{\sum X}{N}
$$

Dimana :

$\bar{X} \quad=$ nilai rata-rata

$\sum X=$ jumlah nilai peserta tes dan

$\mathrm{N}=$ jumlah peserta tes (Purwanto, 2009)

Data tes hasil belajar dianalisa dengan menggunakan rumus rata-rata nilai, daya serap dan ketuntasan belajar klasikal. Rata-rata, Daya serap dan ketuntasan belajar klasikal dikatakan meningkat apabila rata-rata, daya serap dan ketuntasan belajar klasikal silklus III lebih baik dari siklus II dan siklus I. Kemampuan pemecahan masalah dan hasil belajar peserta didik dikatakan meningkat apabila nilai kemampuan pemecahan masalah dan hasil belajar pada siklus III lebih baik dari siklus II dan siklus I. Dan dikatakan tuntas apabila peserta didik mencapai nilai KKM yaitu 73 .

1. Nilai Rata - rata

$$
\bar{X}=\frac{\sum X}{N}
$$

Ket $: \bar{X} \quad=$ Nilai rata-rata

$\sum X \quad=$ Jumlah nilai peserta tes

$\mathrm{N} \quad=$ Jumlah peserta tes [5].

2. Standar Deviasi

$$
\mathrm{S}=\sqrt{\frac{(X-\bar{X})^{2}}{N-1}}
$$

Ket: $S=$ Standar deviasi

$\mathrm{X} \quad=$ Nilai peserta didik

$\bar{X} \quad=$ Nilai rata-rata

$\mathrm{N} \quad=$ Jumlah peserta didik [6].

3. Ketuntasan Belajar Klasikal

$$
K B=\frac{N^{\prime}}{N} \times 100 \%
$$

Ket $: \mathrm{KB}=$ ketuntasan belajar klasikal

$\mathrm{N}^{\prime}=$ jumlah siswa yang skornya $\geq 75$

$\mathrm{N}=$ jumlah siswa keseluruhan

4. Daya Serap

$$
D S=\frac{N S}{s x N I} \times 100 \%
$$

Ket $:$ DS = daya serap peserta didik

NS = Jumlah nilai seluruh peserta didik

$\mathrm{NI}=$ nilai ideal dan

$\mathrm{S}=$ adalah jumlah peserta tes [5]. 


\section{Hasil dan Pembahasan}

\subsection{Aktivitas Belajar Peserta Didik Tiga Siklus}

Aktivitas belajar peserta didik dinilai dari aspek aktivitas belajar berdasarkan tahaptahap metode Cooperative Problem Solving. Aktivitas belajar peserta didik dipengaruhi oleh aktivitas guru sehingga dilakukan pengamatan pada aktivitas guru dan aktivitas peserta didik oleh pengamat I dan pengamat II selama proses pembelajaran tiap siklus berlangsung.

Ada 12 aspek aktivitas peserta didik yang telah diamati pada setiap siklus. Semua aspek aktivitas tersebut telah dilaksanakan dan terdapat beberapa kekurangan. Sehingga dilakukan refleksi pada siklus I yang bertujuan untuk memperbaiki proses pembelajaran pada siklus ke II, dan pada siklus II aktivitas guru dan peserta didik dalam proses pembelajaran masih terdapat kekurangan-kekurangan dan harus di lakukan refleksi guna memperbaiki siklus selanjutnya. Peningkatan aktivitas peserta didik dapat dilihat pada gambar 1.

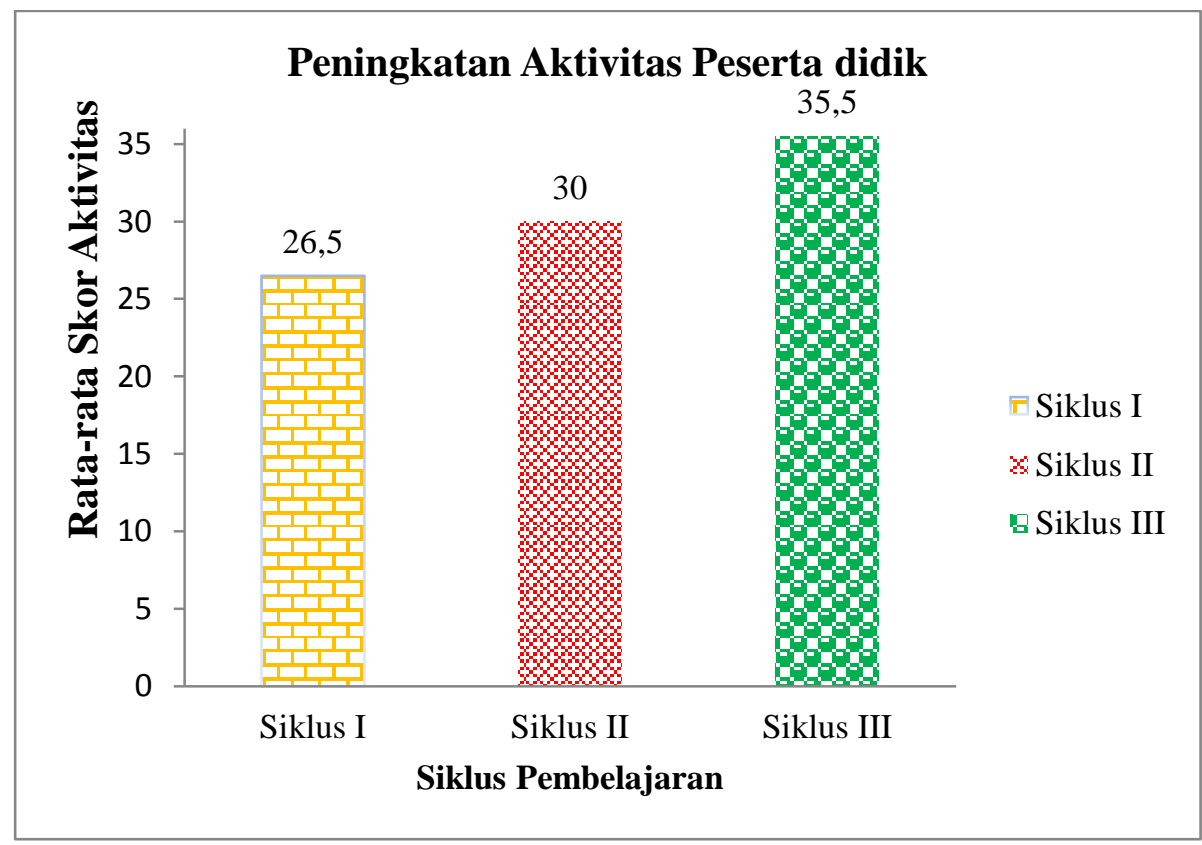

Gambar 1. Grafik Rata-rata hasil Observasi Aktivitas Peserta didik

Berdasarkan gambar 1, diketahui bahwa aktivitas peserta didik pada ketiga siklus meningkat dari siklus I ke siklus II dan dari siklus II ke siklus III. siklus I di kategorikan cukup dengan rata-rata 26,5, untuk siklus II dan siklus III dikategorikan baik dengan rata-rata 31 dan 34,5 .

Peningkatan aktivitas belajar peserta didik tidak lepas dari peranan guru yang memfasilitasi, membimbing, dan mengarahkan serta memotivasi peserta didik. Kemampuan guru mengemas pembelajaran menjadi menarik menjadi salah satu poin yang bagus untuk menciptakan suasana pembelajaran yang aktif dan kondusif.

\subsection{Kemampuan Pemecahan Masalah Peserta Didik Tiga Siklus}

Hasil persentase tiap tahapan kemampuan pemecahan masalah peserta didik dapat dilihat dari gambar 2 . 


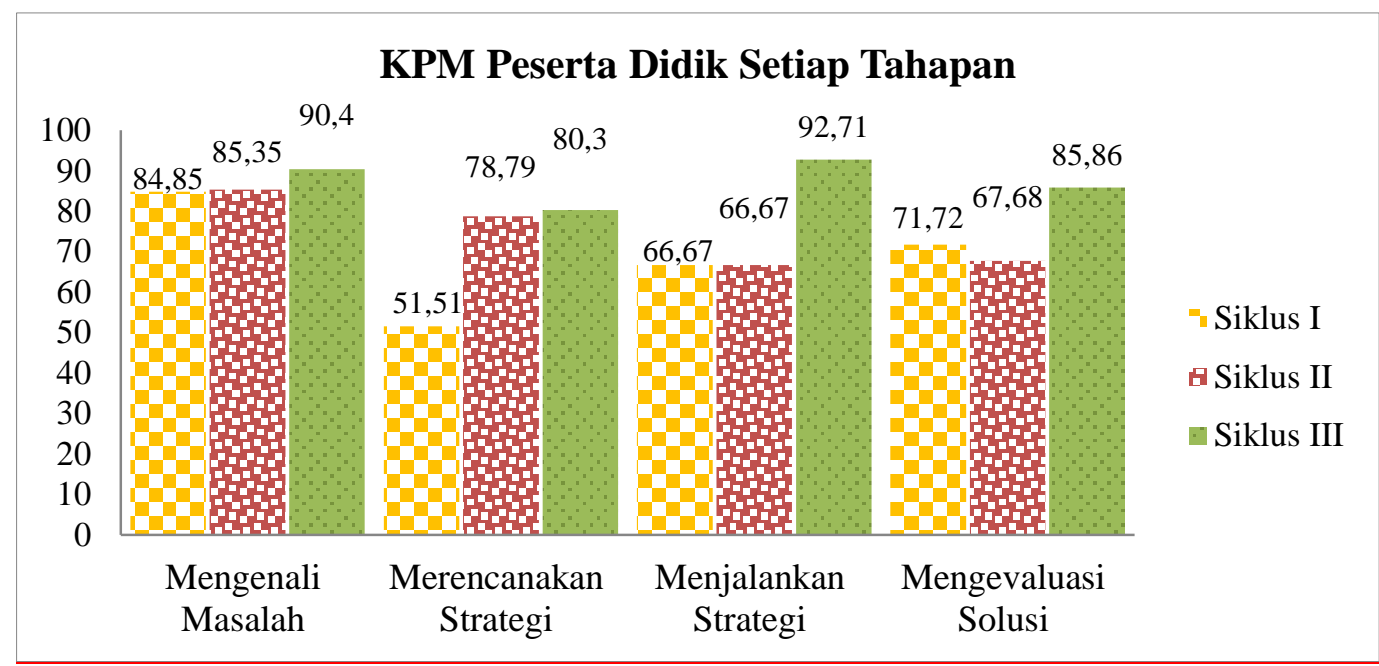

Gambar 2. Kemampuan Pemecahan Masalah Peserta Didik setiap tahap

Berdasarkan grafik tersebut, dapat dilihat bahwa kemampuan pemecahan masalah pada tahap mengenali masalah dan merencanakan strategi telah meningkat dari siklus I ke siklus II, dan dari siklus II ke siklus III. Untuk Tahapan menjalankan rencana telah mengalami peningkatan dari siklus I ke siklus II dan dari siklus II ke siklus III. Pada tahap yang terakhir yaitu tahap mengevaluasi solusi, pada tahap ini terjadi penurunan dari siklus I ke siklus II , hal ini kemungkinan disebabkan pada siklus II peserta didik terburu-buru untuk istirahat, namun pada sikluss III tahapan ini sudah lebih baik dari siklus II dan I.

Kemampuan pemecahan masalah pada ketiga siklus dapat dilihat pada gambar 3.3

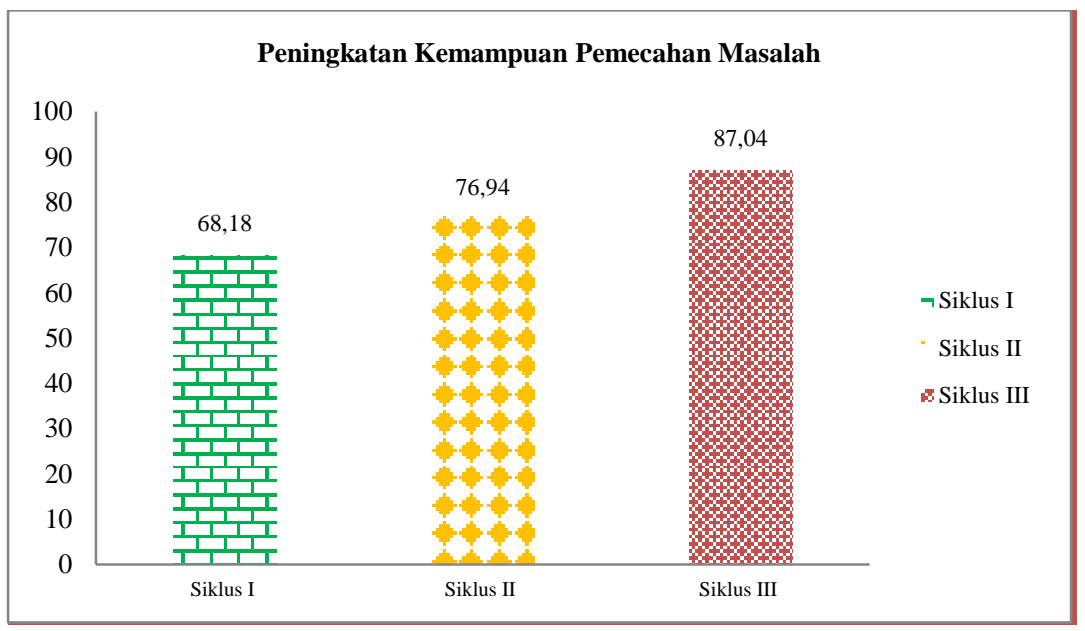

Gambar 3. Kemampuan Pemecahan Masalah Peserta Didik

Berdasarkan grafik diatas dapat dilihat bahwa kemampuan pemecahan masalah peserta pada ketiga siklus dengan penerapan metode Cooperative Problem Solving telah mengalami peningkatan. Adanya peningkatan kemampuan pemecahan masalah dikarenakan pada setiap siklus guru telah melakukan refleksi berdasarkan hasil pengamatan-pengamatan yang dilakukan oleh dua orang pengamat terhadap aktivitas pembelajaran dengan menerapkan metode Cooperative Problem Solving. Hal ini sejalan dengan penelitian Ratnaningdyah (2017) dalam jurnal penelitiannya bahwa Cooperative Problem Solving dapat meningkatkan kemampuan pemecahan masalah peserta didik dan sesuai dengan yang dikemukakan oleh Heller \& Heller (2010) bahwa metode Cooperative Problem Solving dapat meningkatkan kemampuan pemecahan masalah fisika peserta didik.

\subsection{Hasil Belajar Peserta Didik Tiga Siklus}




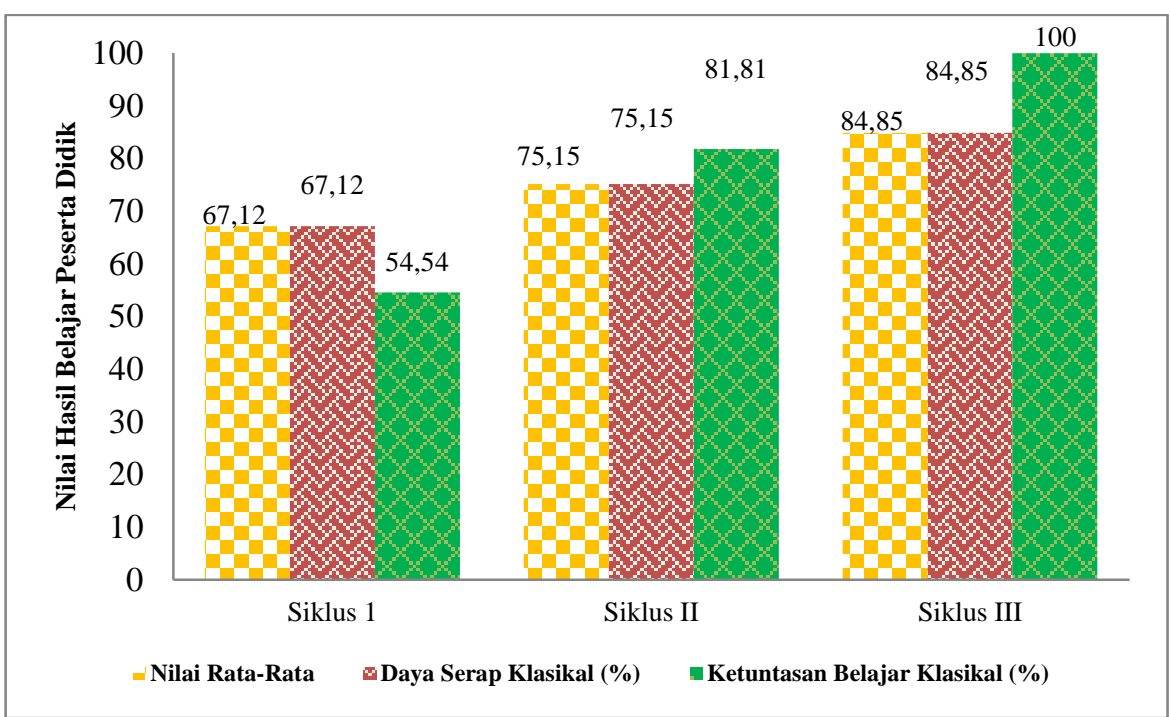

Gambar 4. Grafik Nilai Rata-Rata, Daya Serap dan Ketuntasan Belajar

Berdasarkan pada gambar 4 dikatahui bahwa adanya peningkatan hasil belajar pada tiap siklusnya. Pada siklus I perolehan nilai rata-rata peserta didik yaitu sebesar 67,12, daya serap sebesar $67,12 \%$ dan ketuntasan belajar sebesar 54,54\% sehingga secara klasikal hasil belajar peserta didik belum tuntas. Karena ketuntasan belajar peserta didik atau jumlah peserta didik yang mendapat nilai akhir $\geq 73$ hanya mencapai 54,54\% sedangkan kriteria ketuntasan belajar klasikal adalah apabila peserta didik yang mendapat nilai $\geq 73$ telah mencapai $85 \%$. Pada siklus II perolehan nilai rata-rata peserta didik yaitu sebesar 75.15 , daya serap sebesar $75,15 \%$ dan ketuntasan belajar sebesar $81,81 \%$ sehingga secara klasikal hasil belajar peserta didik sudah tuntas secara klasikal karena kriteria ketuntasan belajar peserta didik itu apabila peserta didik yang mendapat skor $\geq 75$ mencapai $85 \%$. Pada siklus III diperoleh nilai rata-rata sebesar 84,85 , daya serap sebesar $84,85 \%$ dan hasil belajar peserta didik telah tuntas secara klasikal, terlihat pada ketuntasan belajar atau jumlah peserta didik yang mendapat skor $\geq 73$ telah mencapai $100 \%$.

Peningkatan hasil belajar pengetahuan pada tiap siklus ini menjelaskan bagaiamana penguasaan peserta didik terhadap materi yang diajarkan. Dalam hal ini peran guru sebagai motivator, fasilitator dan desain pembelajaran sangat membantu peserta didik dalam belajar. Berdasarkan uraian diatas, maka dapat kita lihat bahwa penerapan metode Cooperative Problem Solving dapat meningkatkan hasil belajar peserta didik pada ranah pengetahuan.

\section{Kesimpulan dan Saran \\ 4.1 Kesimpulan}

Berdasarkan hasil penelitian dan pembahasan diperoleh kesimpulan sebagai berikut : (1) Penerapan metode Cooperative Problem Solving pada konsep Usaha dan Energi dapat meningkatkan aktivitas belajar peserta didik kelas X IPA 2 SMAN 10 Kota Bengkulu., (2) Penerapan metode Cooperative Problem Solving pada konsep Usaha dan Energi dapat meningkatkan kemampuan pemecahan masalah peserta didik kelas X IPA 2 SMAN 10 Kota Bengkulu, (3) Penerapan metode Cooperative Problem Solving pada konsep Usaha dan Energi dapat meningkatkan hasil belajar pengertahuan peserta didik kelas X IPA 2 SMAN 10 Kota Bengkulu.

\subsection{SARAN}

Bagi penelitian selanjutnya sebaiknya memberikan bimbingan dan perhatian yang lebih merata pada setiap kelompok sehingga mengurangi peluang siswa bermain-main saat pembelajaran berlangsung dan sebaiknya tingkat kesulitan soal pada tiap siklusnya disamakan 
meskipun materinya berbeda, hal ini untuk menghindari peningkatan hasil belajar yang tidak merata pada tiap siklus

\section{DAFTAR PUSTAKA}

[1]Kulsum, \& Nugroho. (2014). Penerapan Model Pembelajaran Cooperative Problem Solving Untuk Meningkatkan Kemampuan Pemahaman Konsep Dan Komunikasi Ilmiah Pada Mata Pelajaran Fisika. Unnes Physics Education Journal, 3, 74-78.

[2]Kurnia, S. D., Bakti, M., \& Sri, M. (2014). Studi Komparasi Metode Pembelajaran Kooperative (TAI) dan (CPS) Terhadap Prestasi Belajar Ditinjau Dari Kemampuan Matematik Siswa Pada Materi Kelarutan Dan Hasil Kali Kelarutan Kelas XI IPA SMA Negeri 1 Banyudono Tahun Pelajaran 2012/2013. Jurnal Pendidikan Kimia, 3, 51-57.

[3]Gok, T., \& Silay, I. (2010). The effects of Problem Solving Strategies On Students' Achievement, Attitude and Motivation. Jornal Physics Eduaction, 4, 7-14.

[4]Ninik, Hobri, \& Suharto. Analisis Kemampuan Pemecahan Masalah Untuk Setiap Tahap Model Polya Dari Siswa SMK IBU PAKUSARI Jurusan Multimedia Pada Pokok Bahasan Program Linear. Kadikma, 5, 61-68.

[5]Purwanto, A. (2009). Penerapan Media Jejaring Sosial "Facebook" Pada Mata Kuliah Termodinamika. Jurnal Exacta, 7, 49-55.

[6]Widiyanto, M. A. (2013). Statistika Terapan. Jakarta: PT Elex Media Komputindo.

[7]Sinaga, E., Rahmad, M., \& Irianti, M. (2014). Penerapan Model Pembelajaran Problem Based Learning (PBL) Untuk Meningkatkan Kemampuan Memecahkan Masalah Fisika Di Kelas XI IPA SMAN 2 Teluk Kuantan. Jurnal Pendidikan Fisika Universitas Riau.

[8]Ratnaningdyah, D. (2017). Melatihkan kemampuan pemecahan masalah melalui pembelajaran fisika dengan model Cooperative Problem Solving (CPS). Jurnal Ilmu Pendidikan Fisika, 2.

[9]Heller, K. H. (2010). Cooperative Problem Solving In physics A User's Manual. U.S: University Of Minnesota. 